\title{
CRISPR/Cas9基因编辑技术在线虫中的应用进展 和展望
}

\author{
曹绪文 ${ }^{1,2,3}$, 张留所 $^{1,2 *}$
}

1. 中国科学院海洋研究所实验海洋生物学重点实验室, 青岛 266071;

2. 青岛海洋科学与技术国家实验室, 海洋生物学与生物技术功能实验室, 青岛 266237;

3. 中国科学院大学, 北京 100049

* 联系人, E-mail: 1zhang@qdio.ac.cn

收稿日期：2017-11-30; 接受日期：2018-02-16; 网络版发表日期：2018-04-16 中国科学院海洋研究所海外高层次引进人才、青岛市创业创新领军人才及中国科学院实验海洋生物学重点实验室海洋生物重大成果支持计 划资助

\begin{abstract}
摘要 线虫属于线虫动物门, 从陆地到海洋, 从浅海到深海, 线虫可以生存于几乎所有可栖息环境, 是地球上数量 最多的多细胞动物. 线虫中不仅有生物医学研究领域的明星模式生物秀丽线虫(Caenorhabditis elegans), 还包括对 海洋生态环境具有重要意义的自由生活海洋线虫, 以及引起人类、牲畜和农作物寄生虫病的寄生线虫等. 近几年 来, CRISPR/Cas9基因编辑技术的快速发展和广泛应用, 带动了生命科学研究技术的革命. CRISPR/Cas9技术具有 易构建、成本低、靶点广、效率高的优点, 很快就成为了研究者不可缺少的实验工具. 利用CRISPR/Cas9基因编 辑技术研究线虫领域的重要科学问题, 将加速人们对基因功能和重要生命过程规律的深入解析, 并大大促进与线 虫紧密关联的人类健康、产业经济和生态环境等领域的发展。本文总结了近期CRISPR/Cas9基因编辑技术在秀 丽线虫以及其他线虫中应用的一些重要进展, 并对其应用前景和未来的热点研究领域进行展望.
\end{abstract}

关键词 线虫, CRISPR/Cas9, 基因编辑, 基因敲除, 基因敲入

线虫动物门是动物界中最大的门之一，它们分布 于地球的各个角落, 成功适应了几乎所有的生态系统. 线虫中营自由生活的秀丽线虫(Caenorhabditis elegans) 具有全体透明、结构简单、生命周期短、细胞 谱系(cell lineage)明确并且神经细胞连接图谱(connectome)也已被解析等诸多优点, 使其成为了广泛应用于 生物医学领域研究的模式生物. 自由生活的海洋线虫 是海洋小型底栖动物中的最优势类群，参与海洋微食
物网, 在海洋生态系统中扮演着重要的角色, 并且海 洋线虫对因污染造成的环境变化相当敏感, 是海洋环 境监测的潜在指示生物 ${ }^{[1]}$. 另外, 寄生线虫引发的各种 寄生虫病不仅危害人类健康, 而且会对牲畜和农作物 及其产业发展造成严重损害. 所以对线虫的研究，尤 其是在基因功能水平上的研究, 具有重要的科学和社 会经济意义.

近年来，第三代基因编辑技术成簇规律间断短回

引用格式: 曹绪文, 张留所. CRISPR/Cas9基因编辑技术在线虫中的应用进展和展望. 中国科学: 生命科学, 2018, 48: 513-520 Cao X W, Zhang L S. Application advances and prospects of CRISPR/Cas9 genome editing in nematodes (in Chinese). Sci Sin Vitae, 2018, 48: 513-520, doi: $10.1360 / \mathrm{N} 052017-00284$ 
文重复序列(clustered regularly interspaced short palindromic repeats, CRISPR)得到了飞速的发展，尤其是 CRISPR/Cas9 (CRISPR/CRISPR associated protein 9) 技术更是掀起了基因编辑的革命浪潮. CRISPR/Cas9 基因编辑技术理论和体外验证实验2012年发表在 Science 上 $^{[2]}$, 很快, 2013年初Science同一期两篇文章同 时报道了该技术在人类和小鼠(Mus musculus)细胞系 成功实现精准敲除目标基因 ${ }^{[3,4]}$ ，紧接着CRISPR/Cas9 技术在线虫、果蝇(Drosophila melanogaster)、斑马鱼 (Danio rerio)、小鼠(Mus musculus)和拟南芥(Arabidopsis thaliana) 等模式生物 ${ }^{[511]}$, 以及多种非模式生物 中成功应用 ${ }^{[12]}$. 相较于第一代基因编辑技术锌指核酸 酶(zinc-finger nucleases，ZFNs)和第二代基因编辑技 术类转录激活因子效应物核酸酶(transcription activator-like effector nucleases, TALENs), CRISPR/Cas9集 合了操作简单、成本低、靶点选择广、效率高等优 点, 现已成为当今生物学领域最重要的核心技术之一.

本文将从CRISPR/Cas9基因编辑技术的原理、 CRISPR/Cas9在秀丽线虫和其他线虫中的应用及应用 前景和展望等方面进行总结和分析.

\section{CRISPR/Cas9基因编辑技术的原理}

CRISPR/Cas系统最早发现于细菌和古细菌的适 应性免疫系统中，其通过RNA引导的核酸酶切割外来 的遗传因子，从而抵抗入侵的质粒或噬菌体 $\mathrm{DNA}^{[13,14]}$. 目前研究最多、应用最广泛的是来源于酿脓链球菌 (Streptococcus pyogenes)的依赖Cas9蛋白的2类(class 2) II 型(type II) CRISPR系统, 即CRISPR/Cas9系统. 该 系统中, 核酸内切酶Cas9切割与 crRNA (CRISPR RNA）5'端20个核苷酸碱基互补配对的DNA序 列 ${ }^{[2,15,16]}$. 另一个RNA分子— tracrRNA（trans-activating crRNA), 通过碱基配对与 crRNA形成复合物, 负责 结合并引导Cas9核酸酶发挥作用. Doudna和Charpentier 研究组 ${ }^{[2]}$ 将 crRNA和tracrRNA融合为一个向导 RNA—sgRNA (single guide RNA), 她们的改造使 Cas9系统发挥功能只需要Cas9核酸酶和sgRNA两种组 分，更加方便了应用. 此外, Cas9识别的靶序列下游必 须紧邻着PAM区(protospacer adjacent motif), 最常用的 来源于酿脓链球菌的 SpCas9特异性识别的PAM序列 为 $\mathrm{NGG}^{[2]}$. 当DNA上与 $\mathrm{DgRNA} 5^{\prime}$ 端互补的序列和相邻
的PAM序列同时存在时，Cas9蛋白的两个关键核酸酶 结构域RuvC和 $\mathrm{HNH}$ 就会同时发挥作用，分别切割与 sgRNA 5'端序列相同和互补的DNA单链，从而造成靶 DNA的双链断裂 (double-strand breaks, DSBs) ${ }^{[17,18]}$. 一 般会在PAM序列上游约 3 个碱基对处形成一个平末端 的双链断裂(图1 $)^{[2,19]}$.

DNA双链断裂后, 主要有两种途径进行损伤修复. （i ）在无修复模板存在的情况下，主要通过易出错的 非同源末端连接(non-homologous end joining, NHEJ) 修复断裂的双链DNA. NHEJ容易产生随机的插入/缺 失(indel)突变, 如果插入或缺失在外显子内, 则极可能 造成移码突变, 并产生提前的终止密码子, 导致基因敲 除(knockout, KO). (ii ) 同源介导修复(homology directed repair, HDR), 在有外源引入的修复模板存在的情 况下(具有同源臂的质粒、双链PCR产物或单链DNA 寡核苷酸都可以作为模板 $\left.{ }^{[6,22 \sim 24]}\right)$ ，依赖同源重组能够 对靶点进行精确、特定的编辑(图1) ${ }^{[21,25,26]}$.

\section{CRISPR/Cas9技术在秀丽线虫中的应用}

自从CRISPR/Cas9技术在秀丽线虫中成功应用 ${ }^{[5,6]}$ 以来，为了更高的编辑效率、更强的特异性、更方便 的突变䇻选检测以及更好地满足实验要求等, 研究者 不断对CRISPR/Cas9系统在秀丽线虫中的应用进行优 化. 例如, 加州大学伯克利分校的Meyer研究组 ${ }^{[27]}$ 发现, 当靶位点的 $3^{\prime}$ 末端序列为 $G G$ 时，可以显著增强基因编 辑的效率. 为了突破PAM区序列只能为 $\mathrm{NGG}$ 的限制, Bell等人 ${ }^{[28]}$ 将两个改造后分别识别PAM序列为NGA和 NGCG的Cas9蛋白成功应用于秀丽线虫基因编辑, 增 加了研究者选择靶点的范围. 另外, 研究者开发的 coCRISPR方法, 将具有易识别表型的标记基因和目的基 因的靶 $g$ RNA共同导入，通过标记基因的表型判断 Cas9发挥作用的个体，从而提高对突变的篮选效

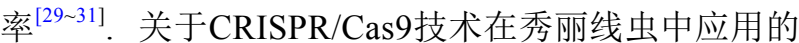
更多优化策略，中国科学技术大学光寿红研究组、浙 江大学徐素宏研究组等已发表数篇优秀的文章进行了 详细综述 ${ }^{[19,20,32 ~ 35]}$, 本文不再赘述.

CRISPR/Cas9技术不仅能够在秀丽线虫中进行基 因敲除和精确的基因敲入(knockin, KI), 而且可以经过 巧妙的实验设计和改造以解决更多的科学问题. 本部 分将重点阐述近期CRISPR/Cas9技术在秀丽线虫中的 


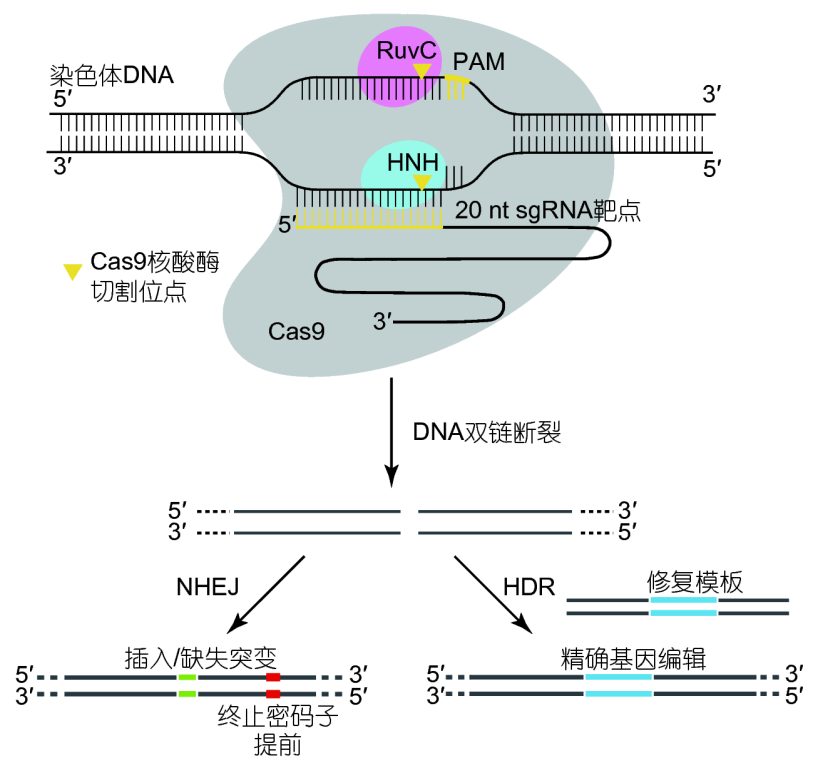

图 1 CRISPR/Cas9基因编辑原理图解, 参考[20,21]并修改 sgRNA $5^{\prime}$ 端 20 个核苷酸(nucleotide, nt) 通过碱基互补配对与靶位点 结合, 引导Cas9核酸内切酶上的两个活性结构域RuvC和HNH分别 切割DNA的两条单链, 在PAM区上游 3 个碱基对处形成平末端的双 链断裂. DNA双链断裂后, 主要有两种修复模式. 通过NHEJ途径的 修复易产生随机的插入/缺失突变, 从而导致终止密码子提前. 依赖 修复模板, HDR 修复能够进行精确的基因编辑

应用, 为研究者拓宽视野, 提供思路.

\section{1 基因敲除和基因敲入}

利用CRISPR/Cas9技术在秀丽线虫中能轻易实现 高效的基因敲除和基因敲入, 本部分着重介绍近两年 CRISPR介导的基因敲除与敲入在与本研究组研究相 关的神经生物学领域的一些应用进展. 2016年, 清华大 学欧光朔研究组 ${ }^{[36]}$ 利用CRISPR技术获得了多个基因 的绿色荧光蛋白 (green fluorescent protein, GFP) knockin线虫品系, 系统研究了神经细胞迁移的分子机制. 紧 接着该研究组又借助CRISPR构建了多个基因的GFP knockin和mMaple3 knockin线虫品系, 分别研究了感知 神经纤毛的肌动蛋白CHE-3 在鞭毛内的动态变化和功 能调控; 以及秀丽线虫神经纤毛形成中中心体转运和 降解的机制 ${ }^{[37,38]} .2017$ 年, 中国科学技术大学单革研究 组 ${ }^{[39]}$ 通过CRISPR 获得了转录因子UNC-30和UNC-55 的GFP knockin线虫品系, 结合染色质免疫共沉淀-测 序(ChIP-Seq), 深入研究了秀丽线虫氨基丁酸运动神 经元(GABAergic motor neurons)突触联系再特化(re- specification)的分子机制. 2017年，Abiusi等人 ${ }^{[40]}$ 发现 人类关节孪缩症的致病基因 $U N C-50$, 作者利用 CRISPR敲入构建了具有人类疾病相同突变的线虫突 变体, 揭示了UNC-50调控乙酰胆碱受体转运而致病的 机制. 此外, Riveiro等人 ${ }^{[41]}$ 利用CRISPR技术揭示了组 氨酸去甲基化酶JMJD-1.2 调控秀丽线虫轴突导向 (axon guidance)的机制. 同样在2017年，Sharifnia等 人 $^{[42]}$ 通过CRISPR技术研究了 $c e b p$ - 1 基因顺式调控元 件在秀丽线虫神经发育中的作用. 最近, 中国科学院神 经科学研究所的蔡时青研究组 ${ }^{[43]}$ 在Nature 上报道了秀 丽线虫雄性交配能力衰老的机制, 作者利用CRISPR技 术构建了特异的神经肽RGBA-1及其受体NPR-28的突 变体, 系统研究了胶质细胞-神经信号调控线虫衰老速 率的分子机制.

\section{2 体细胞条件性基因编辑}

欧光朔研究组 ${ }^{[44-47]}$ 开发了利用CRISPR/Cas9技术 在秀丽线虫体细胞中进行条件特异性基因敲除的策 略, 他们通过选择合适的特异启动子控制Cas9核酸内 切酶在不同发育阶段或不同组织中表达，实现了时空 特异敲除靶基因的目的. 这种体细胞CRISPR/Cas9基 因编辑策略可以绕开胚胎发育时期或只在特定组织敲 除目的基因, 有助于特定基因如纯合致死基因功能的 研究, 尤其是生殖和胚胎发育相关的基因.

\section{3 结合 Cre和FLP的组织特异性基因敲除}

位点特异性重组酶Cre (causes recombination)和 FLP (flippase)广泛用于在特异组织或细胞中精确激活 或沉默基因功能. 2017年, Muñoz-jiménez等人 ${ }^{[48]}$ 结合 FLP和CRISPR 技术实现了线虫特定组织 $b a f-1$ 基因的 敲除. 此外, 蔡时青研究组 ${ }^{[43]}$ 利用CRISPR 并结合Cre分 别特异性敲除了胶质细胞、神经细胞和肠道的神经肽 基因 $r g b a-1$, 并系统研究了 $r g b a-1$ 在雄性秀丽线虫交配 行为中发挥作用的机制. CRISPR/Cas9结合Cre/LoxP 或FLP/FRT重组系统, 为详细分析特定组织生命过程 机制提供了高效的新方案.

\section{4 蛋白质功能的条件性破坏}

秀丽线虫中蛋白质表达相关的技术已经非常成 熟, 但是对蛋白质功能进行条件性破坏的工具还有很 多应用限制. 针对这一问题, Dernburg研究组 ${ }^{[49]}$ 改造了 
植物中发现的生长素诱导降解系统(auxin-inducible degradation, AID). 他们发现, 在秀丽线虫中, 修饰后的 拟南芥TIR1 F-box蛋白可以介导降解决定子(degron) 标记的靶位点降解. 通过CRISPR/Cas9基因组编辑将 degron标签引入靶点, 结合不同启动子和 $3^{\prime}$ 非翻译区 (untranslated region, UTR)控制TIR1表达，可以实现蛋 白质的条件性降解.

近期, 加州大学圣地亚哥分校Oegema研究组 ${ }^{[50]}$ 也 开发出一种新的高效组织特异性蛋白降解方法. 首先 利用CRISPR/Cas9将GFP标签导入目的基因内源基因 座中，然后用特异启动子起始表达以GFP为靶标的纳 米抗体和包含泛素连接酶接头蛋白的细胞因子信号转 导抑制因子(suppressor of cytokine signaling, SOCS)盒, 最终做到了对GFP标记靶蛋白的降解. 这些报道都为 秀丽线虫中蛋白质时空调控和功能分析的研究提供了 有效的新工具.

\section{5 构建遗传平衡子}

遗传平衡子(genetic balancers)包括染色体倒位、 易位以及交换抑制等，其允许致死或不育的突变以杂 合子的形式稳定地保存下来. 传统的平衡子品系获得 一般通过离子辐射或化学诱变造成染色体重排，这种 方法非常繁琐耗时，且可能在构建过程中引入未知的 突变. 中国科学技术大学光寿红研究组 ${ }^{[51]}$ 利用 CRISPR/Cas9技术，开发出诱导染色体易位、产生遗 传平衡子的方法，并且将这种方法应用到了对秀丽线 虫必需基因的编辑上，通过共注射两个靶点在不同染 色体上的sgRNA，它们同时引导Cas9核酸内切酶切割 靶基因座，最终引发两个非同源染色体间的相互易位。 这些染色体易位的个体随后与具有正常染色体的野生 型个体杂交，得到的 $\mathrm{F}_{1}$ 后代可再次利用CRISPR/Cas9 对目的基因进行编辑. 这种方法能够快速高效的得到 特定的染色体易位品系，轻松产生并维持必需基因的 丧失功能等位基因, 而且具有详细的遗传背景信息. 随后，Mitani研究组 ${ }^{[52]}$ 同样通过CRISPR/Cas9技术，系 统地构建了特定位点的染色体倒位、易位和交换抑制 平衡子. 并且他们构建的交换抑制平衡子品系包含荧 光标记, 利于后续的篎选和分析.

\section{6 细胞谱系示踪}

20 世纪 80 年代初，Sulston等人 ${ }^{[53]}$ 利用光学显微镜
观察，追踪秀丽线虫从受精卵至新孵化幼体发育过程 中的每个细胞，揭示了秀丽线虫早期胚胎发育中严格 编排的细胞谱系，并且每个细胞都能够追踪到其直系 祖先. 结合他之前观察并解析的秀丽线虫从新孵化幼 体至成体的胚后发育细胞谱系 ${ }^{[54]}$ ，使得秀丽线虫成为 第一个，也是目前为止唯一一个有完整细胞谱系树的 多细胞生物，完整且明确的细胞谱系为秀丽线虫的研 究提供了巨大便利。

通过确定和映射单个细胞产生的子代的谱系示 踪，是阐明从发育到疾病等各种生命过程潜在机制的 重要方法. 斯坦福大学的Quake研究组 ${ }^{[55]}$ 利用CRISPR/ Cas9技术开发了一种基于动态序列的条形码系统，将 其用于谱系示踪，并在秀丽线虫中验证了它的表现. 他们使用的策略是将特定突变引入细胞中，这些具有 特定突变的DNA条形码在每次细胞分裂中都会传递 给子细胞, 基于此来分析建立谱系树. 同期, 其他研究 者报道了基于CRISPR技术编辑条形码用于谱系示踪 的策略在细胞系和斑马鱼系统中也得以实现 ${ }^{[56-60]}$.

\section{CRISPR/Cas9技术在其他线虫中的应用}

\section{1 卫星模式线虫}

营自由生活的线虫Pristionchus pacificus与秀丽线 虫属于同一目中不同的科，是模式生物秀丽线虫的卫 星模式动物，常用于与秀丽线虫的发育机制比较以及 进化生物学研究中. CRISPR/Cas9基因编辑系统已经 在Pristionchus pacificus 中建立起来并用于基因功能的 研究. 2015年，Witte等人 ${ }^{[61]}$ 利用公司合成的Cas9蛋白 和 $d p y-1$ sgRNA，成功获得了基因编辑后具有粗短 (dumpy)表型的突变体. 随后, Markov等人 ${ }^{[62]}$ 利用Witte 发表的方法通过CRISPR基因编辑得到了硫解酶基因 $d a f-22$ 的功能缺失突变体, 并利用突变体研究了 daf-22 基因在休眠中的作用. 最近Sommer研究组 ${ }^{[63,64]}$ 也利用 上述CRISPR基因编辑技术成功获得了 daf-21/hsp 90 和 血清素合成酶 $t p h-1$ 的突变体，并深入研究了上述基因 在嘴部形态变化和饮食行为中的作用.

\section{2 寄生线虫}

寄生线虫感染威胁人类健康，降低认知和生育能 力，增加由其他病原如HIV、疮疾和肺结核等所致疾 病的严重程度. 全球范围内, 寄生线虫的感染人数超 
过10亿，寄生线虫疾病尤其给不发达和发展中国家造 成了沉重的健康和经济负担 ${ }^{[65 ~ 67]}$. 另外, 寄生线虫也 危害粮食作物和牲畜, 造成严重的减产 ${ }^{[68,69]}$. 其中, 植 物寄生线虫对全球粮食安全造成了严重的威胁，每年 估计造成 800 亿美元的损失 ${ }^{[70]}$; 寄生线虫对牛羊等牲 畜行业每年造成的经济损失估计也有几百亿美元 ${ }^{[69]}$. 许多寄生线虫有复杂的生活史，基因功能和分子机制 的研究面临着很多挑战.

2017年，Gang等人 ${ }^{[71]}$ 利用CRISPR/Cas9技术成功 获得了人类寄生线虫Strongyloides stercoralis肌肉痉 挛基因 $u n c-22$ 突变体，而且进一步通过CRISPR利用修 复模板同时获得了 unc-22突变和红色苂光蛋白基因敲 入; 作者同时也获得了大鼠(Rattus norvegicus) 寄生线 虫Strongyloides ratti的CRISPR 基因编辑unc-22突变体. 上述工作首次在寄生线虫中实现了 CRISPR 基因编辑 技术, 突破了寄生线虫没有定点基因突变体的历史.

\section{CRISPR/Cas9技术在线虫中的应用前景 和展望}

CRISPR/Cas9基因编辑技术的出现和发展极大减 少了反向遗传学研究技术上的障碍, 为生命科学研究 带来了突破性的技术革命. 以下 3 个方面可能成为未 来CRISPR/Cas9技术在线虫中应用的热点. (i) 将 GFP或其他荧光蛋白利用CRISPR/Cas9敲入染色体基 因组, 标记特定的内源基因, 能够检测基因原始的表达
和调控模式, 并可以结合ChIP-Seq深入研究相关蛋白 的作用机制 ${ }^{[36-39,72]}$. (ii) CRISPR/Cas9结合Cre/LoxP或 FLP/FRT重组系统进行组织和细胞特异性的精确基因 编辑, 从而深入研究基因发挥作用的时空调节机 制 ${ }^{[43,48]}$. (iii) 利用CRISPR/Cas9对单个细胞编辑生成 特定的条形码, 用于谱系示踪和分析, 可能在发育生 物学、分子存储、癌症生物学等领域有广泛应 用 ${ }^{[55 \sim 00]}$. 另外, 秀丽线虫每个神经细胞之间的连接已经 被完全解析，在秀丽线虫中利用CRISPR/Cas9结合多 种遗传学方法在神经生物学领域的研究, 现在和未来 都将一直是热点方向.

已经有研究利用CRISPR/Cas9技术实现了寄生线 虫的定点基因编辑 ${ }^{[71]}$, 在分子和基因水平上对寄生线 虫的研究有助于应对寄生线虫疾病，对人类健康、畜 牧养殖和农作物种植及其产业发展都具有重要意义.

相比于陆地生物, 目前对于海洋生物的研究还相 当缺乏, 并且层次不够深入, 这和传统海洋生物研究 难度大、起步晚有关. 海洋线虫不仅在海洋生态环境 中扮演重要角色，它们中的一些种类和秀丽线虫类似， 同样具有易于观察、身体结构简单、细胞数量少、生 命周期短等优点, 海洋线虫在发育调控、神经生物学 和生态环境适应等领域有巨大的实验研究价值. 虽然 现在还没有CRISPR技术在海洋线虫中应用的报道, 相 信CRISPR/Cas9基因编辑技术很快将会成功应用于某 种或几种典型海洋线虫, 并在将其发展成为模式海洋 动物过程中发挥重要作用.

\section{参考文献}

1 杜永芬, 高抒, Warwick R M, 等. 海岸带湿地自由生活海洋线虫的生态功能研究进展. 科学通报, 2014, 59: 3043-3056

2 Jinek M, Chylinski K, Fonfara I, et al. A programmable dual-RNA-guided DNA endonuclease in adaptive bacterial immunity. Science, 2012, 337: 816-821

3 Cong L, Ran F A, Cox D, et al. Multiplex genome engineering using CRISPR/Cas systems. Science, 2013, 339: 819-823

4 Mali P, Yang L, Esvelt K M, et al. RNA-guided human genome engineering via Cas9. Science, 2013, 339: 823-826

5 Friedland A E, Tzur Y B, Esvelt K M, et al. Heritable genome editing in C. elegans via a CRISPR-Cas9 system. Nat Methods, 2013, 10: 741-743

6 Dickinson D J, Ward J D, Reiner D J, et al. Engineering the Caenorhabditis elegans genome using Cas9-triggered homologous recombination. Nat Methods, 2013, 10: 1028-1034

7 Gratz S J, Cummings A M, Nguyen J N, et al. Genome engineering of Drosophila with the CRISPR RNA-guided Cas9 nuclease. Genetics, 2013, 194: 1029-1035

8 Bassett A R, Tibbit C, Ponting C P, et al. Highly efficient targeted mutagenesis of Drosophila with the CRISPR/Cas9 system. Cell Rep, 2013, 4: $220-228$

9 Hwang W Y, Fu Y, Reyon D, et al. Efficient genome editing in zebrafish using a CRISPR-Cas system. Nat Biotechnol, 2013, 31: 227-229 
10 Wang H, Yang H, Shivalila C S, et al. One-step generation of mice carrying mutations in multiple genes by CRISPR/Cas-mediated genome engineering. Cell, 2013, 153: 910-918

11 Jiang W, Zhou H, Bi H, et al. Demonstration of CRISPR/Cas9/sgRNA-mediated targeted gene modification in Arabidopsis, tobacco, sorghum and rice. Nucleic Acids Res, 2013, 41: e188

12 Sander J D, Joung J K. CRISPR-Cas systems for editing, regulating and targeting genomes. Nat Biotechnol, 2014, 32: 347-355

13 Terns M P, Terns R M. CRISPR-based adaptive immune systems. Curr Opin Microbiol, 2011, 14: 321-327

14 Wiedenheft B, Sternberg S H, Doudna J A. RNA-guided genetic silencing systems in bacteria and archaea. Nature, 2012, 482: 331-338

15 Garneau J E, Dupuis M È, Villion M, et al. The CRISPR/Cas bacterial immune system cleaves bacteriophage and plasmid DNA. Nature, 2010, 468: $67-71$

16 Mojica F J M, Díez-Villaseñor C, García-Martínez J, et al. Short motif sequences determine the targets of the prokaryotic CRISPR defence system. Microbiology, 2009, 25: 733-740

17 Sapranauskas R, Gasiunas G, Fremaux C, et al. The Streptococcus thermophilus CRISPR/Cas system provides immunity in Escherichia coli. Nucleic Acids Res, 2011, 39: 9275-9282

18 Sternberg S H, Redding S, Jinek M, et al. DNA interrogation by the CRISPR RNA-guided endonuclease Cas9. Nature, 2014, 507: 62-67

$19 \mathrm{Xu}$ S. The application of CRISPR-Cas9 genome editing in Caenorhabditis elegans. J Genet Genomics, 2015, 42: 413-421

20 Chen X, Feng X, Guang S. Targeted genome engineering in Caenorhabditis elegans. Cell Biosci, 2016, 6: 60

21 Ran F A, Hsu P D, Wright J, et al. Genome engineering using the CRISPR-Cas9 system. Nat Protoc, 2013, 8: 2281-2308

22 Paix A, Wang Y, Smith H E, et al. Scalable and versatile genome editing using linear DNAs with microhomology to Cas9 sites in Caenorhabditis elegans. Genetics, 2014, 198: 1347-1356

23 Zhao P, Zhang Z, Ke H, et al. Oligonucleotide-based targeted gene editing in C. elegans via the CRISPR/Cas9 system. Cell Res, 2014, 24: 247250

24 Paix A, Folkmann A, Seydoux G. Precision genome editing using CRISPR-Cas9 and linear repair templates in C. elegans. Methods, 2017, 121122: $86-93$

25 Hsu P D, Lander E S, Zhang F. Development and applications of CRISPR-Cas9 for genome engineering. Cell, 2014, 157: 1262-1278

26 Doudna J A, Charpentier E. The new frontier of genome engineering with CRISPR-Cas9. Science, 2014, 346: 1258096

27 Farboud B, Meyer B J. Dramatic enhancement of genome editing by CRISPR/Cas9 through improved guide RNA design. Genetics, 2015, 199: 959-971

28 Bell R T, Fu B X H, Fire A Z. Cas9 variants expand the target repertoire in Caenorhabditis elegans. Genetics, 2016, 202: 381-388

29 Arribere J A, Bell R T, Fu B X H, et al. Efficient marker-free recovery of custom genetic modifications with CRISPR/Cas9 in Caenorhabditis elegans. Genetics, 2014, 198: 837-846

30 Ward J D. Rapid and precise engineering of the Caenorhabditis elegans genome with lethal mutation co-conversion and inactivation of NHEJ repair. Genetics, 2015, 199: 363-377

31 Kim H, Ishidate T, Ghanta K S, et al. A co-CRISPR strategy for efficient genome editing in Caenorhabditis elegans. Genetics, 2014, 197: 10691080

32 孟曦男, 周恒达, 徐素宏. CRISPR-Cas9基因编辑技术在秀丽线虫中的应用. 生物工程学报, 2017, 33: 1693-1699

33 Dickinson D J, Goldstein B. CRISPR-based methods for Caenorhabditis elegans genome engineering. Genetics, 2016, 202: 885-901

34 Sugi T. Genome editing in C. elegans and other nematode species. Int J Mol Sci, 2016, 17: 295

35 Farboud B. Targeted genome editing in Caenorhabditis elegans using CRISPR/Cas9. WIREs Dev Biol, 2017, 6: e287

36 Zhu Z, Chai Y, Jiang Y, et al. Functional coordination of WAVE and WASP in C. elegans neuroblast migration. Dev Cell, 2016, 39: 224-238

37 Yi P, Li W-J, Dong M-Q, et al. Dynein-driven retrograde intraflagellar transport is triphasic in C. elegans sensory cilia. Curr Biol, 2017, 27: 1448-1461. e1447

38 Li W, Yi P, Zhu Z, et al. Centriole translocation and degeneration during ciliogenesis in Caenorhabditis elegans neurons. EMBO J, 2017, 36 : 2553-2566

39 Yu B, Wang X, Wei S, et al. Convergent transcriptional programs regulate cAMP levels in C. elegans GABAergic motor neurons. Dev Cell, 2017, 43: 212-226.e7

40 Abiusi E, D'Alessandro M, Dieterich K, et al. Biallelic mutation of UNC50, encoding a protein involved in AChR trafficking, is responsible for 
arthrogryposis. Hum Mol Genet, 2017, 26: 3989-3994

41 Riveiro A R, Mariani L, Malmberg E, et al. JMJD-1.2/PHF8 controls axon guidance by regulating Hedgehog-like signaling. Development, 2017, 144: $856-865$

42 Sharifnia P, Kim KW, Wu Z, et al. Distinct cis elements in the 3'UTR of the C. elegans cebp-1 mRNA mediate its regulation in neuronal development. Dev Biol, 2017, 429: 240-248

43 Yin J A, Gao G, Liu X J, et al. Genetic variation in glia-neuron signalling modulates ageing rate. Nature, 2017, 551: 198-203

44 Shen Z, Zhang X, Chai Y, et al. Conditional knockouts generated by engineered CRISPR-Cas9 endonuclease reveal the roles of coronin in $C$. elegans neural development. Dev Cell, 2014, 30: 625-636

45 Li W, Yi P, Ou G. Somatic CRISPR-Cas9-induced mutations reveal roles of embryonically essential dynein chains in Caenorhabditis elegans cilia. J Cell Biol, 2015, 208: 683-692

46 Tian D, Diao M, Jiang Y, et al. Anillin regulates neuronal migration and neurite growth by linking RhoG to the actin cytoskeleton. Curr Biol, 2015, 25: 1135-1145

47 Li W, Ou G. The application of somatic CRISPR-Cas9 to conditional genome editing in Caenorhabditis elegans. genesis, 2016, 54: 170-181

48 Muñoz-jiménez C M, Ayuso C, Dobrzynska A, et al. An efficient FLP-based toolkit for spatiotemporal control of gene expression in Caenorhabditis elegans. Genetics, 2017, 206: 1763-1778

49 Zhang L, Ward J D, Cheng Z, et al. The auxin-inducible degradation (AID) system enables versatile conditional protein depletion in C. elegans. Development, 2015, 142: 4374-4384

50 Wang S, Tang N H, Lara-Gonzalez P, et al. A toolkit for GFP-mediated tissue-specific protein degradation in C. elegans. Development, 2017, 144: 2694-2701

51 Chen X, Li M, Feng X, et al. Targeted chromosomal translocations and essential gene knockout using CRISPR/Cas9 technology in Caenorhabditis elegans. Genetics, 2015, 201: 1295-1306

52 Iwata S, Yoshina S, Suehiro Y, et al. Engineering new balancer chromosomes in C. elegans via CRISPR/Cas9. Sci Rep, 2016, 6: 33840

53 Sulston J E, Schierenberg E, White J G, et al. The embryonic cell lineage of the nematode Caenorhabditis elegans. Dev Biol, 1983, 100: 64-119

54 Sulston J E, Horvitz H R. Post-embryonic cell lineages of the nematode, Caenorhabditis elegans. Dev Biol, 1977, 56: 110-156

55 Schmidt S T, Zimmerman S M, Wang J, et al. Quantitative analysis of synthetic cell lineage tracing using nuclease barcoding. ACS Synth Biol, 2017, 6: 936-942

56 Callaway E. The trickiest family tree in biology. Nature, 2017, 547: 20-22

57 Frieda K L, Linton J M, Hormoz S, et al. Synthetic recording and in situ readout of lineage information in single cells. Nature, 2017, 541: 107111

58 McKenna A, Findlay G M, Gagnon J A, et al. Whole-organism lineage tracing by combinatorial and cumulative genome editing. Science, 2016, 353: aaf7907

59 Perli S D, Cui C H, Lu T K. Continuous genetic recording with self-targeting CRISPR-Cas in human cells. Science, 2016, 353: aag0511

60 Kalhor R, Mali P, Church G M. Rapidly evolving homing CRISPR barcodes. Nat Methods, 2017, 14: 195-200

61 Witte H, Moreno E, Rödelsperger C, et al. Gene inactivation using the CRISPR/Cas9 system in the nematode Pristionchus pacificus. Dev Genes Evol, 2015, 225: 55-62

62 Markov G V, Meyer J M, Panda O, et al. Functional conservation and divergence of daf-22 paralogs in Pristionchus pacificus dauer development. Mol Biol Evol, 2016, 33: 2506-2514

63 Sieriebriennikov B, Markov G V, Witte H, et al. The role of DAF-21/Hsp90 in mouth-form plasticity in Pristionchus pacificus. Mol Biol Evol, 2017, 34: 1644-1653

64 Okumura M, Wilecki M, Sommer R J. serotonin drives predatory feeding behavior via synchronous feeding rhythms in the nematode Pristionchus pacificus. G3 (Bethesda), 2017, 7: 3745-3755

65 Hotez P J, Brindley P J, Bethony J M, et al. Helminth infections: the great neglected tropical diseases. J Clin Invest, 2008, 118: 1311-1321

66 Lustigman S, Prichard R K, Gazzinelli A, et al. A research agenda for helminth diseases of humans: the problem of helminthiases. PLoS Negl Trop Dis, 2012, 6: e1582

67 Ward J D. Rendering the intractable more tractable: tools from Caenorhabditis elegans ripe for import into parasitic nematodes. Genetics, 2015, 201: $1279-1294$ 

961

Roeber F, Jex A R, Gasser R B. Impact of gastrointestinal parasitic nematodes of sheep, and the role of advanced molecular tools for exploring epidemiology and drug resistance-an Australian perspective. Parasit Vect, 2013, 6: 153

70 Jones J, Gheysen G, Fenoll C. Genomics and Molecular Genetics of Plant-Nematode Interactions. Berlin: Springer, 2011

71 Gang S S, Castelletto M L, Bryant A S, et al. Targeted mutagenesis in a human-parasitic nematode. PLoS Pathog, 2017, 13: e1006675

72 Chen B, Gilbert L A, Cimini B A, et al. Dynamic imaging of genomic loci in living human cells by an optimized CRISPR/Cas system. Cell, 2013, 155: 1479-1491

\title{
Application advances and prospects of CRISPR/Cas9 genome editing in nematodes
}

\author{
CAO XuWen ${ }^{1,2,3} \&$ ZHANG LiuSuo ${ }^{1,2}$ \\ 1 CAS Key Laboratory of Experimental Marine Biology, Institute of Oceanology, Chinese Academy of Sciences, Qingdao 266071, China; \\ 2 Laboratory for Marine Biology and Biotechnology, Qingdao National Laboratory for Marine Science and Technology, Qingdao 266237, China; \\ 3 University of Chinese Academy of Sciences, Beijing 100049, China
}

Nematodes that belong to the Phylum Nematoda are the most abundant multicellular animals on earth. They are widespread in almost all ecosystems and habitats throughout the planet, including the land and the sea (both shallow sea and deep sea). In the Phylum Nematoda, Caenorhabditis elegans is a popular model organism used in biomedical research, although other organisms such as freeliving marine nematodes and parasitic nematodes are also the research focus because of their important roles in marine ecological systems or their roles as pathogens of parasitic diseases in humans, livestock, and crops. In recent years, the rapid development and the widespread application of genome editing techniques based on the clustered regularly interspaced short palindromic repeats (CRISPR)/Cas9 system have revolutionized research in biological sciences. Because of the advantages of simple design, low cost, wide range of targets, and high efficiency, the CRISPR/Cas9 system is rapidly becoming an indispensable experimental tool for the entire biological and medical fields. The application of CRISPR/Cas9 technology for studying the nematode worms can help researchers further investigate the function of genes and the associated biological processes, which is essential for our health, society, and environment. In this review, we summarize the recent progress made in the application of the CRISPR/Cas9 genome editing technique in $C$. elegans and other nematodes. We also discuss the prospects and future application hotspots of this technology in nematodes.

nematodes, CRISPR/Cas9, genome editing, knock-out, knock-in

doi: $10.1360 / \mathrm{N} 052017-00284$ 